International Journal of Engineering \& Technology, 7 (4.20) (2018) 316-320
International Journal of Engineering \& Technology
SPC
Website: www.sciencepubco.com/index.php/IJET
Research paper

\title{
Flexural Behavior of Rubberized Reinforced Concrete Beams
}

\author{
Adel A. Al-Azzawi ${ }^{1 *}$, Dalia Shakir², Noora Saad ${ }^{3}$ \\ ${ }^{1}$ Assistant Professor, Ph.D., Department of Civil Engineering, Al-Nahrain University, Baghdad, Iraq \\ ${ }^{2}$ Assistant Professor, Department of Civil Engineering, Al-Nahrain University, Baghdad, Iraq \\ ${ }^{3}$ Assistant Lecturer, Department of Civil Engineering, Al-Nahrain University, Baghdad, Iraq \\ *Corresponding author E-mail: dr_adel_azzawi@yahoo.com
}

\begin{abstract}
In Iraq, the use of rubber waste material in concrete is an interesting topic due to its availability in large volumes. Researches of applications of rubber waste in concrete have been increased since 2003. Many studies carried out to investigate the performance of concrete using different ratios of rubber as a replacement to fine or coarse aggregate. In this research, rubber wastes from scrapped tires have been added as fiber to concrete mix with presence of $0.5 \%$ superplasticizer. The flexural behavior of concrete beams, mechanical properties of concrete and workability of concrete mixes have been studied. Rubber fibers ranging from (2-4) mm were added in percentages of $0.5 \%$ and $1 \%$ ) of the cement weight. The results have demonstrated that the addition of rubber material as fibers in natural aggregate concrete enhances its ductility, compressive strength and tensile strength compared to the normal concrete. The effect of rubber fiber content is found to be significant on the behavior of tested beams. If the fiber content increased from 0 to $0.5 \%$ the cracking load increased by $60 \%$ and ultimate load increased by $21 \%$. For rubberized concrete, if the fiber content increased from 0.5 to $1.0 \%$, the cracking load decreased $7 \%$ and ultimate load increased by $4 \%$.
\end{abstract}

Keywords: beams, experimental study, finite elements, flexural, rubberized concrete.

\section{Introduction}

Many kinds of waste materials are considered to be additives for concrete. Some of these materials contain; cellulose, fly ash, silica fumes and wood particles. Rubber gained or obtained from disposed tires is considered as the latest waste material that has been investigated due to its availability and use in construction activity. Examinations have been revealed that scrapped rubber tires including materials do not molder under environmental conditions and thus causing dangerous problems. One option of disposal is burning. However, burned tires leave a toxic pottage of pollutants. Using rubber in landfill as alternative to burning causes complex environmental problems as it is not biodegradable. It can be used to develop a new type of concrete by incorporating rubber particles in it.

Ganjian et al. in 2009 have been studied the effect of replacing or exchanging aggregate by tire rubber in the concrete mixtures. The obtained results have showed that the strength in compression has reduced if the percentage of rubber replacement in concrete has increased without noticeable or remarkable changes in other hardened concrete mechanical properties.

Certain researches on studying the properties of recycled aggregate (RA) were progressed since 2011 which consider the durability and response of waste concrete structural elements (RAC) (Marinkovic et al. 2012).

Al-Zahraa et al. (2011) have been investigated experimentally the shear tests on recycled concrete coarse aggregate reinforced beams. Twelve beam specimens with varied content of recycled or waste coarse aggregates, stirrups and shear spans were laboratory tested to resist two point loads until failure.
Fathifazl et al. (2011) investigated the shear response of coarse recycled aggregate beams. The equivalent mortar volume method of mixture was used. Several beams without stirrup were designed and tested for shear based on this new mix design method.

Al-Tayeb et al. (2013) were prepared rubberized concrete specimens by partial substitution $(5 \%, 10 \%$ and $20 \%$ replacements by volume) of sand by waste crumb rubber, and tested under impact three-point bending load, as well as static load. Three types of specimens (size $50 \times 100 \times 500 \mathrm{~mm}$ ) namely, plain concrete, rubberized concrete, and double layer concrete (with rubberized concrete top and plain concrete bottom) were loaded to failure. In both tests, the load- displacement and fracture energy of each specimen were investigated. Finite-element simulations were also performed to study the dynamic behaviors of the samples, by using LUSAS V.14 software. It was noticed that, the impact, and inertial and bending loads increased with the increase in the percentage of sand replacement by crumb rubber.

Arezoumandi et al. (2014) investigated the shear capacity or strength response of beams casted with full waste or recycled concrete aggregate (RCA). This experimental program comprised testing 12 beams (six for each mixture of concrete). The parametric study included steel reinforcement ratio and concrete mixture or type.

Bing and Ning (2014) carried out an experimental study based on using tire rubber particles as a surrogate for natural coarse aggregate in concrete mix. The replacement reduced the concrete compressive strength and Young's modulus of elasticity. Also, the flexural strength of concrete was investigated.

Knaack and Kurama (2015) have been studied the behavior of waste aggregate normal strength concrete beams in both shear and 
flexure. The experimental test results of 12 concrete beam specimens were compared with the relevant code equations.

Choi and Yun (2016) investigated the shear response of concrete beams made of waste aggregate and without stirrups. The test program variables were 3 replacement ratios $(0 \%, 30 \%, 60 \%$, and $100 \%)$ of recycled aggregate and different shear span to depth ratios $(2.0,2.5,3.0,4.0$, and 5.0). The researchers work compared the laboratory results with the results obtained using relevant ACI 318 code equations and equations proposed in the literature. It was found by previous researchers that the code equations can estimate the failure shear loads of waste concrete beams very well and therefore it is possible to use these equations to speculate the shear capacity of structural elements with waste aggregate.

All previous studies on the replacement of aggregate by waste rubber have been showed that the rubber particles adversely affect the mechanical properties of concrete when used as aggregate (Zheng et al. 2008, Ganjian, et al. 2009, Bing and Ning 2014, Gupta et al. 2015). In contrast, Al-Azzawi (2017) has showed that lightweight coarse aggregate concrete mixture had increased mechanical properties with the addition of waste rubber fibers. Also, the shear behavior of RC beams having opening were tested. The existence of an opening in beams reduces the shear and flexural strength and shear and flexural rigidity of beams with a percentage depending on the position of opening, shear reinforcement and waste rubber fiber ratio. The aim of the present study is to introduce an environment friendly technology and explore the influence of rubber fiber obtained from mechanical recycling of waste tires on concrete properties in fresh and hardened state. Also, the flexural of beams with rubber are investigated in addition to their mechanical properties.

\section{Experimental study layout}

\subsection{Materials and Mixing}

In this paper, the used normal concrete mix consist of type I cement complying with the requirements of Iraqi Standards No.5(1984) (tables 1 and 2), coarse aggregate (CA), and fine aggregate (FA). The maximum coarse aggregate size was $10 \mathrm{~mm}$, natural sand used as fine aggregate, table 3 showed the gradation of them according to Iraqi Standards No.45 (1984).

Table 1: Chemical composition of cement

\begin{tabular}{c|c|c}
\hline Compound & Weight, $\%$ & Iraqi Standard No.5(1984) \\
\hline $\mathrm{CaO}$ & 64.12 & - \\
$\mathrm{SiO} 2$ & 20.86 & - \\
$\mathrm{Al}_{2} \mathrm{O}_{3}$ & 3.73 & - \\
$\mathrm{Fe}_{2} \mathrm{O}_{3}$ & 4.51 & $2.8 \%$ maximum \\
$\mathrm{SO}_{3}$ & 2.09 & $5.0 \%$ maximum \\
$\mathrm{Mg} \mathrm{O}$ & 1.01 & $1.5 \%$ maximum \\
Insoluble residue & 0.83 & $4.0 \%$ maximum \\
Loss on ignition & 1.97 & $0.66-1.02$ \\
Lime saturation factor & 0.96 & - \\
$\mathrm{C}_{3} \mathrm{~S}$ & 21.29 & - \\
$\mathrm{C}_{2} \mathrm{~S}$ & 52.31 & $5.0 \%$ minimum \\
$\mathrm{C}_{3} \mathrm{~A}$ & 6.19 & - \\
$\mathrm{C}_{4} \mathrm{~A} \mathrm{~F}$ & 9.31 & \multicolumn{2}{c}{} \\
\hline
\end{tabular}

Table 2: Cement physical properties

\begin{tabular}{c|c|c}
\multicolumn{3}{c}{ Table 2: Cement physical properties } \\
\hline Test & Value & Iraqi Slandered No.5 (1984) \\
\hline Fineness, $\left(\mathrm{m}^{2} / \mathrm{kg}\right)$ & 335 & $\geq 230$ \\
$\begin{array}{c}\text { Setting time, }(\mathrm{hrs}: \mathrm{min}) \\
\text { Initial setting }\end{array}$ & $2: 30$ & $\geq 00: 45$ \\
Final setting & $4: 15$ & $\leq 10: 00$ \\
Compressive strength, & & $\geq 15.00$ \\
$\quad(\mathrm{MPa})$ & 20.30 & $\geq 23.00$ \\
Three days & 26.23 & $\leq 0.80$ \\
$\begin{array}{c}\text { Seven days } \\
\text { Autoclave expansion, } \\
(\%)\end{array}$ & 0.13 & \\
\hline
\end{tabular}


Table 6: Effect of rubber fiber and superplasticizer (SP) on slump and compressive strength of concrete mixes

$\begin{array}{cccccc}\text { Mix } & \text { SP \% } & \begin{array}{c}\text { Rubber } \\ \text { fiber } \\ \%\end{array} & \begin{array}{c}\text { 28-day } \\ \text { Compressive } \\ \text { strength } \\ (\mathrm{MPa})\end{array} & \begin{array}{c}\text { 28-day } \\ \text { Modulus } \\ \text { of Rap- } \\ \text { ture } \\ (\mathrm{MPa})\end{array} & \begin{array}{c}\text { Slump } \\ (\mathrm{mm})\end{array} \\ \text { CM } & - & - & 18.98 & 1.5 & 15 \\ \text { MS } & & - & 21.54 & 1.7 & 35 \\ \text { MSF } & 0.5 & 0.5 & 31.29 & 2.5 & 32 \\ \text { MSF1 } & & 1 & 27.28 & 2.2 & 28\end{array}$

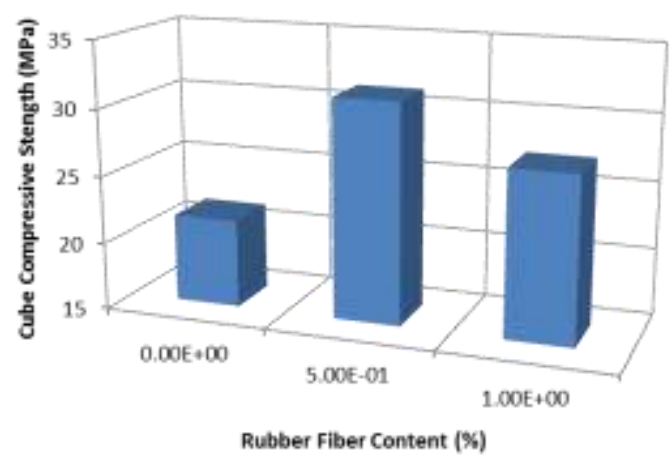

Fig 2: Effect of rubber fiber content on cube compressive strength for $0.5 \%$ superplasticizer mixes

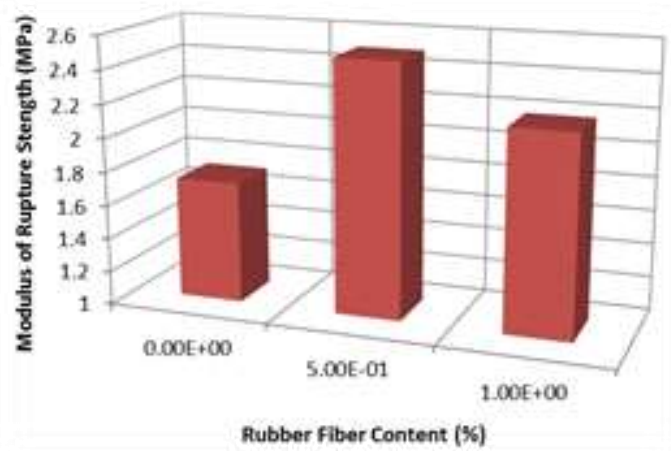

Fig 3: Effect of rubber fiber content on modulus of rupture strength for $0.5 \%$ superplasticizer mixes

The ASTM A615 (2005) specifications are used in carrying steel reinforcement tensile test of $(\varnothing 6 \mathrm{~mm})$ bars. The results of tensile test confirmed with this specification.

\subsection{Testing of Beams}

All beams were simply supported with width $(0.1 \mathrm{~m})$, depth $(0.15 \mathrm{~m})$ and total length of $(1.25) \mathrm{m}$ and subjected to one point loading test. Shear span to effective depth $(\mathrm{a} / \mathrm{d})$ was kept constant with the value of 4 for the tested beams as shown in Figs. 4 and 5. The beams were loaded gradually to failure. The testing was load controlled and the load increment was about one tenth of the expected ultimate load. Beams were tested between 30 to 35 days of casting. The study investigates the flexural behavior of the five concrete beams with different compressive strength and different ratios of rubber fiber, flexural and shear reinforcement as shown in Table 7. The concrete design of beams without fibers was done by the code of ACI-318, (2011). The reinforcement was selected so as to make sure or ensure that the beam section failed in flexure. The main or bottom reinforcement bars consisted of $(2 \varnothing 6 \mathrm{~mm})$ and the compression or top reinforcement bars of $(2 \varnothing 6 \mathrm{~mm})$ Beams (B3, B4 andB5) had 6 stirrups of ( $\varnothing 6 @ 176 \mathrm{~mm} \mathrm{c/c}$ ).

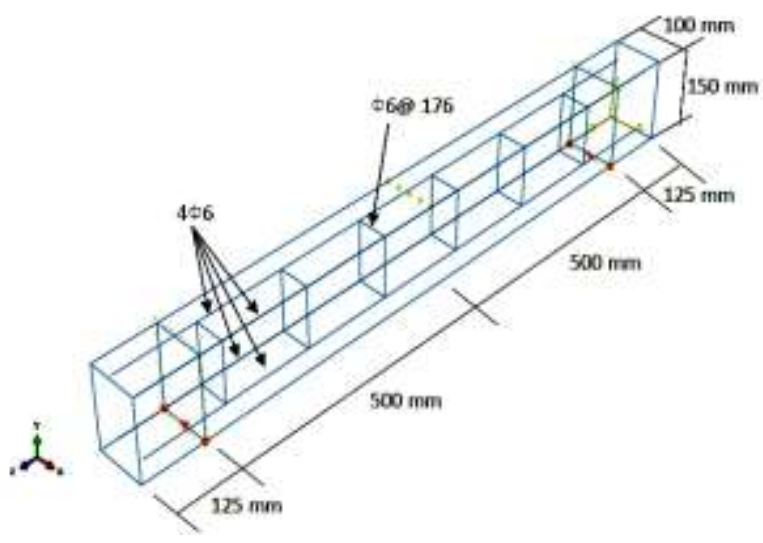

Fig. 4: shows the reinforcement arrangement of the beams.

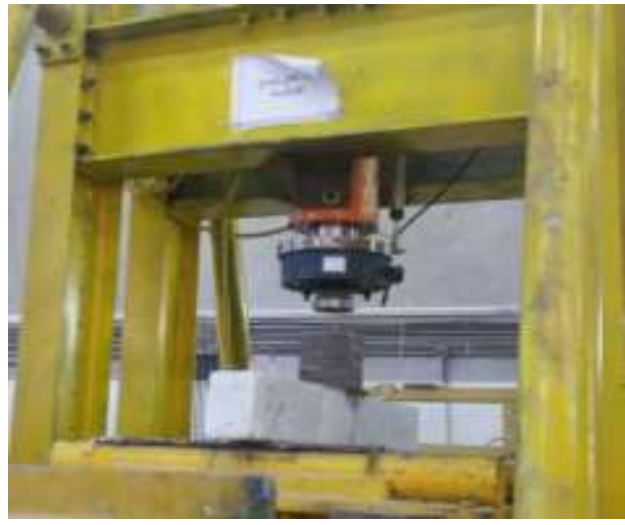

Fig.5: Testing machine

Table 7: Designation and properties of test specimens

\begin{tabular}{c|c|c|c}
\hline Beam No & $\begin{array}{c}\text { Rubber fiber } \\
\text { percentage }(\%)\end{array}$ & $\begin{array}{c}\text { Flexural rein- } \\
\text { forcement }\left(\mathrm{mm}^{2}\right)\end{array}$ & $\begin{array}{c}\text { Shear reinforce- } \\
\text { ment } \\
\left(\mathrm{mm}^{2}\right)\end{array}$ \\
\hline B1 & 1 & 0.0 & without \\
B2 & 1 & 56.5 & without \\
B3 & 0 & & 56.5 \\
B4 & 0.5 & & \\
B5 & 1 &
\end{tabular}

The obtained test results are given in Table 8 and photographs of the tested beam specimens have shown in Fig. 6. The crack pattern and beam behavior were similar for specimens with and without stirrups which are failed in flexure as shown in Fig. 6. The failure happens suddenly in beam specimen (B1) because there is no flexural or shears reinforcements. While all other specimens failed gradually as the flexural cracks developed at the bottom face of the beams and then propagated towards the compression zone. The ultimate load carrying capacity of the tested beam specimens exceed or override the cracking load capacity by varying percentages from 100 to $223 \%$ depending on the fiber content and the existing of shear reinforcement as shown in Table 8. The effect of rubber fiber content is obvious from the comparison of beams B3, B4 and B5 test results. As the fiber ratio or content is increased from 0 to $0.5 \%$ the cracking load is increased by $60 \%$ and ultimate load increased by $21 \%$. The cracking deflection is increased by $70 \%$ and ultimate deflection is increased by $37 \%$. If the fiber ratio or content is increased from 0.5 to $1.0 \%$ the cracking load is decreased $7 \%$ and ultimate load is increased by $4 \%$. Here, the cracking deflection is decreased by $22 \%$ and ultimate deflection is decreased by $15 \%$.

Table 8: Tested beams results

\begin{tabular}{c|c|c|c|c|c|c}
\multicolumn{7}{c}{ Table 8: Tested beams results } \\
\hline $\begin{array}{c}\text { Beam } \\
\text { No. }\end{array}$ & $\begin{array}{c}\mathrm{P}_{\mathrm{cr}}{ }^{*} \\
(\mathrm{kN})\end{array}$ & $\begin{array}{c}\mathrm{D}_{\mathrm{cr}}{ }^{* * *} \\
(\mathrm{~mm})\end{array}$ & $\begin{array}{c}\mathrm{P}_{\mathrm{u}}^{* *} \\
(\mathrm{kN})\end{array}$ & $\begin{array}{c}\mathrm{D}_{\mathrm{u}}{ }^{* * * * *} \\
(\mathrm{~mm})\end{array}$ & $\mathrm{P}_{\mathrm{cr}} / \mathrm{P}_{\mathrm{u}}$ & $\begin{array}{c}\mathrm{D}_{\mathrm{cr}} / \\
\mathrm{D}_{\mathrm{u}}\end{array}$ \\
\hline B1 & - & - & 9.60 & - & - & - \\
B2 & 3.80 & 0.79 & 12.76 & 9.14 & 0.30 & 0.09 \\
B3 & 5.70 & 0.85 & 13.57 & 5.53 & 0.42 & 0.15 \\
B4 & 9.10 & 1.45 & 16.50 & 7.56 & 0.55 & 0.19
\end{tabular}




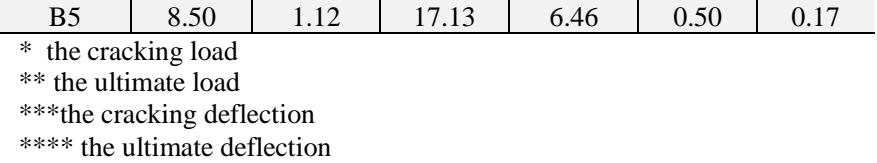

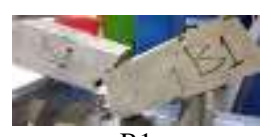

B1

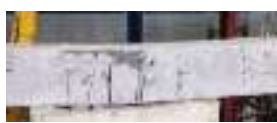

B2

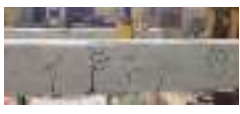

B3

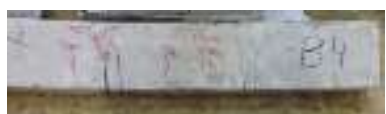

B4

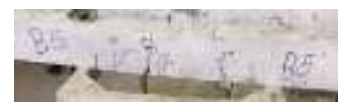

B5
Fig. 6: Crack pattern for the tested beams at failure

Fig. 7 shows the applied point load versus the maximum or midspan displacement or deflection of the present study specimens. The beam B1 fractured quickly; therefore, the load deflection response cannot be drawn. It is obvious from these relationships that the beam without stirrups or shear reinforcement shows approximate linear behavior until first visible crack occurs. After that, the strength and deformation of specimen B2 start to differ from other tested beams with shear reinforcement. The effect of rubber fiber content is obvious from the comparison of beams B3, B4 and B5 load deflection curves of Fig.7. The fiber content does not affect the load deflection response of beams at early stage of load. As the fiber ratio increased from 0 to $0.5 \%$ ultimate load and ultimate deflection increased, therefore, the ductility increased. If the fiber ratio increased from 0.5 to $1.0 \%$ the ultimate load increased and the ultimate deflection decreased, therefore, the ductility decreased. The optimum fiber content is found to be $0.5 \%$.

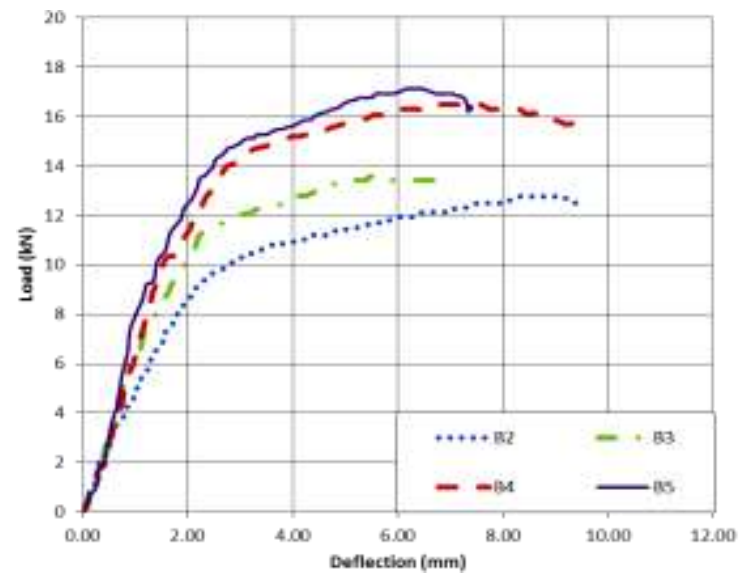

Fig 7: Load deflection curves for the tested beams

\section{Finite element study}

Finite element method has the capability to solve the problems of the complicated geometry and material nonlinear behavior. Three dimensional (3D) finite element models are used in this research. ABAQUS 6.10 software is also used to model the reinforced concrete beams using 20 node brick elements and 3 node truss element to model the flexural and shear reinforcement. The finite element mesh is shown in figure 8. In material modeling, the damage plasticity model is used to model concrete and the steel is modeled as elastic perfectly plastic. The fiber concrete is modeled through the improved material properties when fiber is added especially the tensioning stiffening effect.

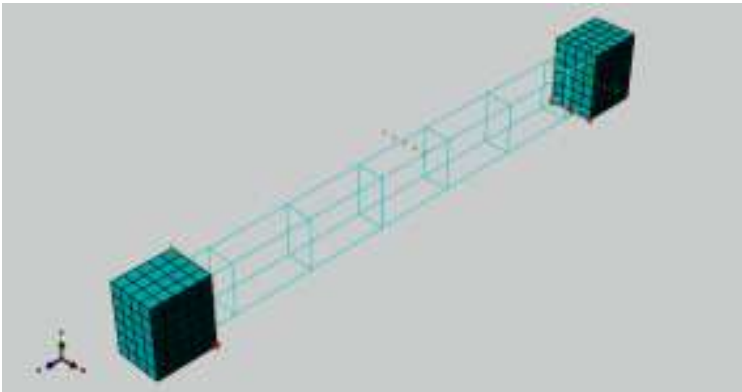

Fig. 8: Finite element mesh (B3, B4 and B5)

\section{Applications}

The numerical results which have been obtained by the method of finite elements have compared with experimental beam test results to check the accuracy of the finite element solution obtained in this study. Beam B4 has selected for a comparison. Figs. 9 to 12 show the load deflection curves obtained from experimental and finite elements. Results are in good agreements between them.

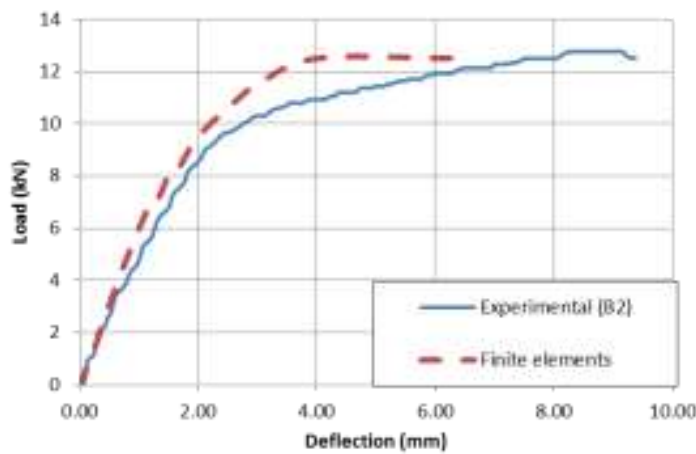

Fig 9: Load deflection curves for the tested beam B2

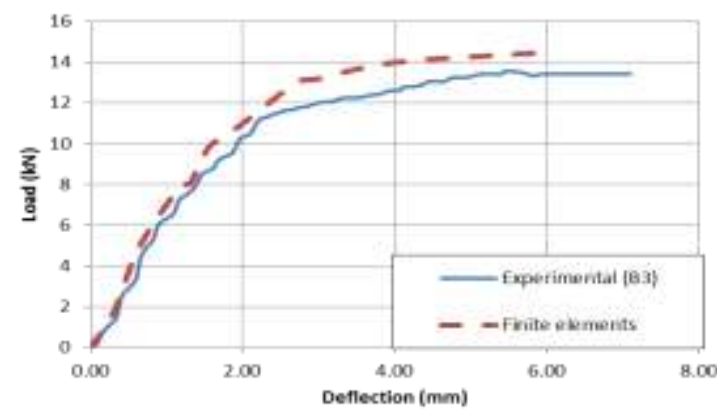

Fig 10: Load deflection curves for the tested beam B3

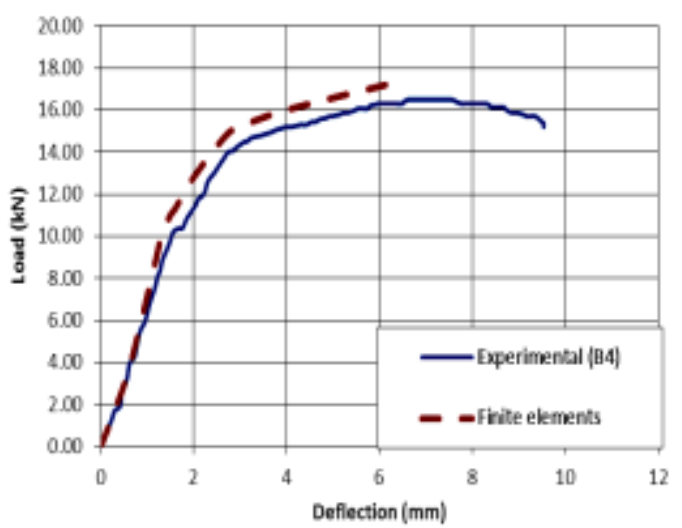

Fig 11: Load deflection curves for the tested beam B4 


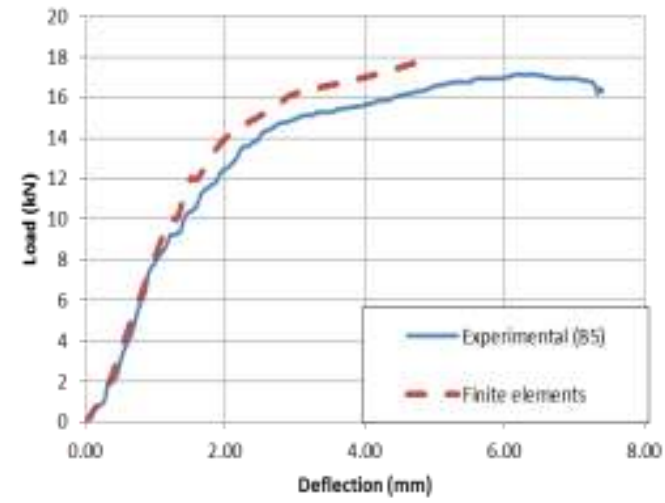

Fig 12: Load deflection curves for the tested beam B5

Table 9 shows the ultimate loads and deflection obtained from experimental and finite elements. The results are in good agreements with average difference of $7 \%$ in ultimate load and $13 \%$ in ultimate deflection.

Table 9: Tested beams experimental and finite elements results

\begin{tabular}{c|c|c|c|c|c|c}
\multicolumn{8}{c}{ Table 9: Tested beams experimental and finite elements results } \\
\hline $\begin{array}{c}\text { Beam } \\
\text { No. }\end{array}$ & $\begin{array}{c}\text { Exp. } \mathrm{P}_{\mathrm{u}} \\
(\mathrm{kN})\end{array}$ & $\begin{array}{c}\text { Exp. } \mathrm{D}_{\mathrm{u}} \\
(\mathrm{mm})\end{array}$ & $\begin{array}{c}\text { FE. } \mathrm{P}_{\mathrm{u}} \\
(\mathrm{kN})\end{array}$ & $\begin{array}{c}\text { FE. } \mathrm{D}_{\mathrm{u}} \\
(\mathrm{mm})\end{array}$ & $\begin{array}{c}\text { Exp } \\
\mathrm{P}_{\mathrm{u}} / \mathrm{FE} \\
\mathrm{P}_{\mathrm{u}}\end{array}$ & $\begin{array}{c}\text { Exp } \\
\mathrm{D}_{\mathrm{u}} / \\
\mathrm{FE} \mathrm{D}_{\mathrm{u}}\end{array}$ \\
\hline B1 & 9.60 & - & 10.34 & - & 0.93 & - \\
B2 & 12.76 & 9.14 & 13.33 & 7.75 & 0.96 & 1.18 \\
B3 & 13.57 & 5.53 & 14.7 & 4.98 & 0.92 & 1.11 \\
B4 & 16.50 & 7.56 & 17.4 & 6.45 & 0.95 & 1.17 \\
B5 & 17.13 & 6.46 & 18.50 & 6.11 & 0.93 & 1.06 \\
\hline
\end{tabular}

\section{Conclusions}

From this study, the main conclusions are given as below: The cube strength of natural aggregate concrete to compression increased by $45 \%$ with increasing fiber content from 0 to $0.5 \%$. After that the compressive strength decreased by $13 \%$. Therefore, the optimal fiber content is found to be $0.5 \%$. Similar conclusion was obtained for modulus of rupture.

The ultimate loads and deflection obtained from experimental and method of finite elements are in good agreement with average difference of $7 \%$ in ultimate load and $13 \%$ in ultimate deflection. As the fiber ratio increased from 0 to $0.5 \%$ the cracking load increased by $60 \%$ and ultimate load increased by $21 \%$. The cracking deflection increased by $70 \%$ and ultimate deflection increased by $37 \%$. If the fiber ratio is increased from 0.5 to $1.0 \%$, the cracking load is decreased $7 \%$ and ultimate load is increased by $4 \%$. Here, the cracking deflection is decreased by $22 \%$ and ultimate deflection is decreased by $15 \%$. This due to the waste material negative effects on the concrete properties when waste increased. The effect of rubber fiber ratio or content is obvious from the comparison of load deflection curves of beams B3, B4 and B5. The fiber ratio or content does not affect the load deflection response of beams at early stage of load. As the fiber ratio increased from 0 to $0.5 \%$ the ultimate load and the ultimate deflection increased, therefore, the ductility increased. If the fiber ratio increased from 0.5 to $1.0 \%$ the ultimate load increased and the ultimate deflection decreased, therefore, the ductility decreased. The optimum fiber content is found to be $0.5 \%$.

\section{References}

[1] ACI 318 (2011), Building code requirements for structural concrete and commentary, American Concrete Institute, Farmington Hills, Michigan.

[2] Al-Zahraa F, El-Mihilmy M and Bahaa T. (2011), "Experimental investigation of shear strength of concrete beams with recycled concrete aggregates", International Journal of Materials and Structural Integrity 5(4), 291-309.
[3] Arezoumandi , M., Smith A., Volz, J. and Khayat, K. H. (2014) "An experimental study on shear strength of reinforced concrete beams with $100 \%$ recycled concrete aggregate", Construction and Building Materials, 53,612-620

[4] ASTM A615(2005), Standard specification for deformed and plain carbon structural steel bars for concrete reinforcement, Manual Book of ASTM Standards.

[5] ASTM C 39 (2004), Standard test method for compressive strength of cylindrical concrete specimens, American Society for Testing and Materials.

[6] ASTM C 78 (2002), Standard test method for flexural strength of concrete, Manual Book of ASTM Standards, Concrete and Aggregates, West Conshohocken, PA, United States.

[7] ASTM C 469 (2002), Standard test method for static modulus of elasticity and Poisson's ratio of concrete in compression, Manual Book of ASTM Standards, Concrete and Aggregates, West Conshohocken, PA, United States.

[8] ASTM C 494 (2005), Standard specification for chemical admixtures for concrete, Manual Book of ASTM Standards.

[9] ASTM C496 (2004), Standard method of test for splitting tensile strength of cylindrical concrete specimens, American Society for Testing and Materials.

[10] BS1881-116 (1997), Method for determination of compressive strength of concrete cubes, British Standards Institute, London.

[11] Choi , W. C. and Yun, H. D. (2016) "Shear strength of reinforced recycled aggregate concrete beams without shear reinforcements", Journal of Civil Engineering and Management, 22 (7),1-9

[12] Fathifazl G, Razaqpur AG, Isgor B, Abbas A and Fournier B, Foo S. (2011), " Shear Capacity Evaluation of Steel Reinforced Recycled Concrete (RRC) Beams", Engineering Structures Journal, 33, 1025-1033.

[13] Iraqi specification No.5 (1984), Portland cement, Central Agency for Standardization and Quality Control, Planning Council, Baghdad, Iraq, translated from Arabic edition.

[14] Iraqi specification No.45 (1984), Aggregate from natural sources for concrete, Central Agency for Standardization and Quality Control, Planning Council, Baghdad, Iraq, translated from Arabic edition.

[15] Knaack AM and Kurama YC. (2015), "Behavior of reinforced concrete beams with recycled concrete coarse aggregates", Journal of Structural Engineering, 141(3).

[16] Meyer, C. (2002), Concrete and sustainable development, Special Publication ACI 206, USA.

[17] Marinkovic, S., Radonjanin, V., Malesev, M. and Ignjatovic', I. (2010) "Comparative environmental assessment of natural and recycled aggregate concrete ", Waste Management 30, 2255-2264

[18] Marinkovic, S., Ignjatovic, I., Radonjanin, V. and Malesev, M. (2012) RAC for structural use - an overview of technologies, properties and applications", Chapter in the book " Innovative materials and techniques in concrete construction. Springer, Netherlands, $115-130$.

[19] Saravanakumar, P. and Dhinakaran, G. (2013), “ Durability characteristics of recycled aggregate concrete", Structural Engineering and Mechanics, 47(5), 701-711.

[20] Shah A., Jan I., Khan, R. and Qazi, E. (2013), “ Experimental investigation on the use of recycled aggregates in producing concrete", Structural Engineering and Mechanics, 47(4), 545-557.

[21] Yang, K.H., Chung, H.S, and Ashour A. (2008), "Influence of type and replacement level of recycled aggregates on concrete properties", ACI Material Journal 105(3), 289-296. 